\title{
A Passage to India: Rhetoric and Diplomacy between Muscovy and Central Asia in the Seventeenth Century
}

\author{
ULFAT ABDURASULOV* \\ E-mail: ulfat.abdurasulov@gmail.com
}

It is broadly assumed that attempts by the Russian state of Muscovy to establish stable diplomatic and mercantile channels to India via Central Asia were started upon the initiative of the Emperor Peter I (1682-1725). Such attempts are generally interpreted as being part of a large-scale project that reflected the growing imperial and colonial ambitions of Russia and which, in turn, entailed strong antagonism from the ruling elites of Central Asia, thereby setting a tone for relations that would continue for the next century and more of reciprocal relations between the local principalities and Russia. By exploring chancellery documents from seventeenth-century Muscovy, we find that the first diplomatic communications between Russia, Khiva, and Bukhara can in fact be dated to long before the reign of Peter I. The first Romanov tsars sought to initiate exchanges with Khiva and Bukhara as a means of establishing diplomatic and commercial ties with the Mughal emperors; at the same time, meanwhile, the authorities in Khiva and Bukhara had their own reasons for pushing Muscovy to engage with Central Asia as a conduit to India. Over the course of the seventeenth century, Central Asian diplomats went to great lengths - both in diplomatic correspondence and through direct interpersonal contacts - to convince their Russian counterparts of the region's attractiveness as a source of precious Indian commodities and as a logistically convenient passage to India. Despite such rhetoric, however, the authorities in Khiva and Bukhara were in fact highly reluctant to "open" the region to Russian agents: repeated attempts by Muscovy to engage in diplomatic fact-finding as a means of establishing influence in the region invariably foundered in the face of Central Asian resistance. Bukharan and Khivan circles seem, in fact, to have held out the enticing idea of "a passage to India" simply as a rhetorical device to secure recognition in Muscovy for their own diplomatic and mercantile missions.

Key words: Khiva, Bukhara, Muscovy, diplomatic texts, passage to India, early modern diplomacy 
In 1716-17, the Russian emperor, Peter I (r. 1696-1725), dispatched an expedition from Astrakhan to the eastern coast of the Caspian Sea and thence up into the territory of the Khorezmian (Arabic, Khwārazm) oasis. One of the goals of the endeavour was to locate and destroy an artificial dam which reportedly had been blocking the flow of the Amu Darya into the Caspian Sea, and thereby to establish a water passage as far as the Mughal realms. In his personal instructions to the head of the expedition, Prince Alexander Bekovich-Cherkassky, ${ }^{1}$ Peter I also ordered him to "incline the khan of Khiva toward loyalty and allegiance (sklonit' $k$ vernosti i poddanstvu)," "to dispatch merchants to the Indian Mughal ( $k$ mogolu Indeiskomu)," and also "to investigate the overland and, especially, the river routes to India." "2 As would soon transpire, things did not turn out quite as hoped.

Upon reaching the Khorezmian borderlands, the party immediately encountered stubborn resistance from the ruler of Khiva, Shīr Ghāzī Khān (r. 1714-28). After several clashes, negotiations followed. The Russian troops were lured into the territory of the Khanate, ${ }^{3}$ where, divided into separate parts, they were captured by Khivan forces, and most of them executed or reduced to slavery. The same fate also befell the expedition leader Prince Bekovich-Cherkassky himself, whose severed head was reportedly presented to the ruler of neighbouring Bukhara. ${ }^{4}$ The episode was a strategic disaster, and memories of the ill-fated expedition continued to colour the dynamics of RussianKhivan relations for centuries to come, as a canonical instance of the supposed treachery and barbarity of the Central Asian regimes - tropes which long remained highly influential among Russian decision-making circles and in public opinion. ${ }^{5}$

Though the details of the expedition are not the focus of the present study, I propose to consider the episode as a vantage point from which to look, not forwards in time like other scholars, but instead backwards, towards earlier political dynamics. The extensive historiography of the Bekovich-Cherkassky expedition is generally inclined to depict the event as a foundational encounter between the Russians and the Central Asian regimes, whilst the figure of Peter I has been memorialised as a pioneer in Russian endeavours to establish diplomatic and trade contacts with the Mughal emperors. ${ }^{6}$ When we begin to excavate the archives of Muscovite chancelleries, however, we find that Russia's diplomatic communications with Khiva and Bukhara can in fact be dated to long before the reign of Peter $\mathrm{I}$.

We may also observe that the authorities in Khiva and Bukhara had their own reasons for pushing Muscovy to engage with Central Asia as a conduit to India. Over the course of the seventeenth century, Central Asian diplomats went to great lengths - both in diplomatic correspondence and through direct interpersonal contacts - to convince their Russian counterparts of the region's attractiveness as a source of precious Indian commodities and as a logistically convenient passage to India. Despite such rhetoric, however, the authorities in Khiva and Bukhara were in fact highly reluctant to open the region to Muscovite agents: repeated attempts by Muscovy to engage in diplomatic factfinding as a means of establishing influence in the region invariably foundered in the face of Central Asian resistance. Bukharan and Khivan circles seem, in fact, to have held out the enticing idea of "a passage to India" mostly as a rhetorical device to secure 
recognition in Muscovy for their own diplomatic and mercantile missions. Such "aggressive tactics"7 - as Audrey Burton termed them - were not due to the duplicity of the local regimes or to native treachery, as conventional readings would have it. Rather, these tactics were informed by the very logic of early modern state formation in Central Asia, whereby acute resource constraints required polities to align their capabilities vis-à-vis broader and much more complex regional dynamics.

In this essay I hope to show that the idea of a passage to India that once appeared to be a fruit of improvisation by Central Asian envoys in Muscovy not only was adopted but also proved to be a full-fledged strategic repertoire interwoven in diplomatic machinery on both sides. It is not to say, of course, that the Russian statesmen blindly believed in the possibility of such a passage; rather they sought to implement this ploy in pursuit of their own strategies.

\section{Russia in the Post-Smuta Period and Visions of India}

The period of political turbulence in Muscovy at the turn of the seventeenth century known as the Time of Troubles (Smutnoe vremia) came to an end in the 1610s with the Romanov accession to power. ${ }^{8}$ The stabilisation of political life after the crisis of the early 1600 s played an important role in enabling the intensification of trade relations and Muscovy's rise to prominence as an intermediator in the trade between East and West. This, in particular, triggered the growth of Astrakhan, a prominent emporium perched on the mouth of the Volga River that, according to Jarmo Kotilaine's observation, by this time was, after Arkhangelsk, "the second most important border point in the realm," and "a truly cosmopolitan city, frequented by merchants from Central Asia, Persia, Turkey and Trans-Caucasia." Astrakhan served as a principal focal point for long-distance trade exchange and diplomatic communication with Central Asia, India, and the steppe zones of Inner Asia. ${ }^{10}$

The Romanovs' interests lay in maintaining the trade with Central Asian merchants because the Khanates of Bukhara and Khiva were the second-largest recipient-after Safavid Iran - of shipments from Astrakhan during the period under study. According to estimates, in the $1670 \mathrm{~s}$ and $1680 \mathrm{~s}$ at least 19.9 percent of total documented traffic across the Caspian Sea went to or from the Central Asian principalities. ${ }^{11}$ This trade was important not just for Muscovy itself, but also for Khivan and Bukharan merchant groups, as well as the ruling elites associated with them. It then does not come as a surprise that throughout the seventeenth century, caravans and ships laden with various wares had been arriving in Astrakhan from Central Asia, seeking to gain access to the sought-after markets of Muscovy. While the presence of Central Asian traders was mostly concentrated in the markets of "downriver towns" (ponizovie goroda) of the lower and middle Volga basins, such as Tsaritsin, Saratov, Samara, Kazan, and Nizhny Novgorod, they were to be found also as far afield as Tver and Arkhangelsk. ${ }^{12}$ They brought to the Muscovite markets various sorts of fabrics, cotton textiles, ready-made garments, and dyes, both of Central Asian origin and reimported from China, India, and Iran. ${ }^{13}$ 
Not only did Muscovite elites seek to exploit new markets, they also endeavoured to profit by connecting them. ${ }^{14}$ The state monopoly that the Muscovy authorities imposed upon a number of transit commodities such as silk, saltpetre, and rhubarb became not only a profitable source of revenue for the treasury, ${ }^{15}$ but also a key means of raising specie and bullion, which were in high demand due to a chronic currency shortage. ${ }^{16}$ As Matthew Romaniello justly noted, establishing relations with Muslim states such as Safavid Persia and Mughal India was thus "a high priority" and presented "tremendous opportunities" for Muscovy, given the wealth and commodities that were to be found in such places. ${ }^{17}$

It is little wonder, therefore, that in such circumstances the Romanovs should have been interested in establishing trade relations also with India. Muscovite political and mercantile circles had long regarded India as a source of everyday commodities (notably cotton and silk textiles) and luxury goods (precious stones, species, dyes) that were in demand both domestically in Russia and elsewhere in Europe. ${ }^{18}$ Such perceptions are echoed in Russian epic poems of the time, which frequently evoke the idea of "rich India" as a wonderland abounding in exotic merchandise. ${ }^{19}$

Despite the absence of direct contacts between the Mughal and Romanov courts throughout most of the seventeenth century, ${ }^{20}$ luxury goods from India were familiar to Russian autocrats due to the diplomatic rituals of gift-exchange (liubitel'nie pominki) with the monarchs of neighbouring realms. In 1641, for instance, the envoy of the Khivan ruler Isfandiyār Khān (r. 1623-42), while in Moscow, presented to Mikhail Fedorovich, the first Romanov tsar (r. 1613-45), as well as to the crown prince and future ruler Aleksey Mikhailovich (r. 1645-76), a number of gifts on behalf of his patron. In his letter to the Romanov prince, the Khivan ruler especially emphasised that he was presenting him with a number of Indian items:

The Indian King (indeiskoi tsar) had sent me crimson velvet as a gift; [now] I am forwarding it to you - also adding two skins of leopard (bars) — via my ambassador as a gift [on my own behalf]. ${ }^{21}$

Indian merchandise - both luxury and mundane — was also familiar to Muscovite circles because of the Indian merchant community, of largely Multani origin, which started to arrive and settle in Muscovy in great numbers following the Romanov ascension to power. $^{22}$ The archive of the Posol'skii Prikaz (Foreign Affairs Chancery) includes a number of documents itemising the gifts and other forms of offerings that were presented to the Romanov dynasts on behalf of various groups of merchants indicated in the documents as of Indian origin (indeiskie kupchiny). ${ }^{23}$ Even a quick glance at these documents reveals a long list of precious goods encrusted with gold and diamonds, as well as various luxury fabrics. Though we cannot be certain of the provenance of all the goods that were presented, the Muscovite authorities themselves seem to have believed that they had come from India. ${ }^{24}$ Indian cottons of many different varieties and other bulk goods constituted the overwhelming majority of India's exports to Muscovite markets. A 1647 edict sent by the tsar to the authorities in Astrakhan may serve as an eloquent illustration of the Muscovy authorities' eagerness to facilitate trade exchange with Indian merchants. The 
edict enjoined local officials to treat Indian traders who arrived in the city with respect and protection, and to honour them "above all other foreigners." Anyone who violated this edict, we read, "will be subjected to great disgrace and cruel execution." 25

During this period we can also observe the initial attempts by the Romanov administration to collect and systematise information about India, notably about the political system, the Mughal rulers, and, most importantly, about the possible routes by which Russians might travel there. ${ }^{26}$ To obtain such information, the Muscovite authorities sought to utilise different channels. First, the tsar's envoys to the courts of foreign rulers were instructed to collect information about Mughal emperors, routes, commodities, and suchlike. The same was true, to a larger extent, of the Russian diplomatic agents in Safavid Iran, who often met Mughal diplomatic emissaries. ${ }^{27}$ No less important was the information obtained from individuals who visited India on various occasions. These were mostly merchants who traded in the region between India and Muscovy, ${ }^{28}$ or individuals who had recently been released from slavery in the Mughal realms. ${ }^{29}$

Yet, despite the seemingly well-developed and sophisticated set of chancellery practices that had developed in Muscovy, people's knowledge about India and the Mughal court seems to have remained superficial, and indeed sometimes in fact apocryphal, throughout the seventeenth century. ${ }^{30}$ For instance, Russian knowledge about the provenance of the Mughal dynasts was confined to the fact that the latter were "scions of Temir Aksak, from the clan of Chagatay," and that they were Muslims. ${ }^{31}$ The Russian geographical imagination also remained rather opaque. We may note, for instance, the Russian diplomatic mission to the Duchy of Courland and Semigallia in 1662. While conversing in Riga with Melchior von Foelckersahm, the Duchy's chancellor, the Muscovite diplomats paid special attention to the case of India. An ambassadorial report penned by the Muscovite envoys reveals the following details of the dialogue between the chancellor and the Russian envoys. Upon the tsar's instructions, the Muscovite envoys questioned their interlocutor in depth about the itinerary and the assortment of goods that Courland ships had taken from their possessions in India. Furthermore, the envoys conveyed the tsar's proposal to build and fit out a ship at Muscovy's expense in order to sail jointly to India. ${ }^{32}$ This all presumably came as a surprise to von Foelckersahm, given that the Courland fleet had seldom ventured into the Indian Ocean, and that the territory which the chancellor of Courland called their "island in India" was in fact the island of Tobago in the West Indies, halfway around the world from the Asiatic East Indies about which the Russian diplomats were speaking. ${ }^{33}$

In 1668-9, under the supervision of a voevoda of Siberia, Petr Godunov (in office 1667-70), a sort of compendium titled "A description of Chinese lands and inner India" was compiled in Tobol'sk. ${ }^{34}$ The new survey was drawn mostly on information gathered from various trading people and diplomatic personnel who travelled to and from China. While it included rather detailed info on the geography, travel routes, and economy of Qing China, next to nothing was said about India. The few lines at the very end of the book devoted to the subject of the Mughal state offered little information that was of use to anyone. ${ }^{35}$ At around the same time, there were also attempts to provide a detailed guide that described the possibility of oversea passage to the South Asian 
region from the city of Arkhangelsk through the Northern Seas. However, this survey similarly was based mostly on legendary sources rather than empirical detail. ${ }^{36}$

During the reign of Mikhail Fedorovich (r. 1613-45), little of substance was done to establish stable relations with the Mughal court. It was only during the reign of Mikhail's son and immediate successor Aleksey Mikhailovich (r. 1645-76) that the Muscovites launched a series of diplomatic missions pursuing this goal, using Central Asia as a possible conduit. He sent the first embassy in 1646, in the opening year of his reign, and would continue to undertake such overtures throughout his thirty-year rule. The last attempt during his lifetime to reach India was undertaken in 1675, the expedition returning to Moscow only after Aleksey's death in 1676. None of those missions, however, would reach the longed-for court of the Mughal emperors.

\section{Pursuing the Mughal Court}

In 1646, two diplomatic missions set off from Moscow nearly simultaneously. The first mission, headed by Duke Savely Kozlovsky, was dispatched to the Safavid ruler Shāh 'Abbās II (r. 1642-66). Kozlovsky was instructed to convey to the shāh the tsar's request that he ensure safe passage for two Russian couriers (gontsy), the Kazan merchant Mikita Syroezhin, and the Astrakhan resident Vasily Tushkanov, who would be passing through Safavid territory. These latter couriers, for their part, were supposed to reach India, and there establish contact with the court of Emperor Shāh Jahān. ${ }^{37}$

Along with this "double" embassy, the Russian court equipped another mission headed by Anisim Gribov, an Astrakhan merchant who had previously led a diplomatic mission to Khiva and Bukhara. ${ }^{38}$ Gribov was instructed to go "to Bukhara, Urgench and Balkh" via the Safavid realms (following the Western Caspian Shamakhi-ArdabilQazvin-Isfahan route) and, if possible, to reach the court of Shāh Jahān. In the instruction (nakaz) given by Muscovite authorities to Gribov, the following tasks were stipulated:

And Anisim Gribov with his partners-upon the edict of Great Sovereign-[is instructed] to investigate, by any measures, [notably] by enquiring of highly knowledgeable people, where lies the most convenient way from Astrakhan to the Indian state: via Urgench or Bukhara or via cities [under the rule of the] Qizilbashs; . . . whether this way is overland or overwater or it passes through the mountains; and what people dwell all along the road up to the Indian realm, and whether they are obedient to Bukhara or Balkh or Urgench or there are self-determined princes [whom they obey]; and if so, who are those princes by name, to whom they may have sworn their allegiance and whether they place any obstacles to the wayfarers- whether tradesmen or civil servants. ${ }^{39}$

Hence, one may safely assume that the three missions were together conceived with the same ultimate goal, namely to establish contact with the court of the Mughal emperor. As it turned out, however, little was achieved. While the embassy of Kozlovsky was treated with all due respect at the court of Shāh 'Abbās II, his request for the two Russian couriers to be escorted into the Mughal realm was rejected. The formal reason for refusal was the conflict that flared up around this time between the Safavids and the Mughals 
over control of Kandahar, as a result of which the Safavid authorities were unable to assure the safe passage of Russian couriers. ${ }^{40}$

No more successful was Anisim Gribov, with his instructions to advance to Mughal India via Central Asia. The envoy was unable to advance farther than Isfahan due to sharp conflict between the rulers of Bukhara and Balkh in $1647 .{ }^{41}$ During his extended sojourn in the Safavid capital, however, Gribov did manage to gather detailed data on the overland passage to India as well as learn about military conflicts both between Balkh and Bukhara and between the Mughals and the Safavids.

Several years later, in 1651, yet another attempt was made to establish a connection between the Romanov and Mughal courts. On this occasion, the initiative came from a group of Moscow merchants who were interested in establishing trade exchange with India. ${ }^{42}$ Although the initiative was supported by the governmental bodies of Muscovy, the outcome of this embassy-cum-trade mission was again disappointing: ${ }^{43}$ the conflict in Shamakhi that broke out in 1651 between the Safavids and the Romanovs prevented its further advance. ${ }^{44}$

Having attained little success in establishing contacts with the Mughal court through Safavid Iran, the Romanovs gradually shifted their focus towards Central Asia. Scholars have suggested possible reasons that pushed Muscovite authorities to consider Bukhara and Khiva as a convenient conduit to India. ${ }^{45}$ According to Rudi Matthee, the period between 1630 and 1650 marked, in general, an attenuation of trade and diplomatic relations between the Safavids and the Romanovs. ${ }^{46}$ No less important, however, were the political dynamics within Central Asia, and particularly in Khorezm. G. L. Penrose, for instance, points to the fact that the accession of Anūsha Khān to the Khivan throne marked a clear break with the policies of his predecessor and father Abu'l Ghāzī Khān (r. 1644-63). Over the reign of Abu'l Ghāzī Khān, commercial and diplomatic liaisons with Muscovite Russia had been significantly damaged, not least due to the former's confrontation with those Turkmen clans who monopolised transportation services through the region of Mangyshlaq. ${ }^{47}$ Unlike his predecessor, Anūsha Khān sought to revitalise the trade relations between Central Asia and Muscovite Russia. Anūsha's rise to power saw Khivan diplomats endeavour to convince their Russian counterparts of the region's attractiveness as a source of precious Indian commodities and as a logistically convenient passage to the subcontinent.

Indeed, during the 1660s and 1670s we can observe an intensification of Russian diplomatic engagement with the region. A key priority for Russian envoys to Central Asian principalities was to investigate the region's capacity to facilitate transit to India and, if possible, to establish contact with Mughal officials. ${ }^{48}$ This, for instance, was the case for the Russian embassy to Khiva in 1669-70 led by the Astrakhan resident Ivan Matveev Fedotov. Fedotov's embassy was organised in response to the Khivan embassy of Pulad Muhammad Bek (Ruzumov), who had arrived in Moscow a year earlier. ${ }^{49}$ On 19 December 1667, in an interview with the prominent statesman Afanasy OrdinNashchokin, head of Posol'skii Prikaz (in office 1667-71), the Khivan envoy painted a rosy picture of how Khorezm might enable Russia to establish trade and diplomatic contacts with India. Not only did Ruzumov emphasise the dynamic trade exchange 
that already existed between Khiva and cities in India, and the bulging stores of Indian commodities that, he said, were to be found throughout Khorezm, but he also undertook to ensure the safety of any Russian who wished to travel to India through Khiva. ${ }^{50}$ Despite Ruzumov's grandiloquent assertions, however, when the Muscovite envoy Ivan Fedotov arrived in Khiva in June 1669 he met with a rather cold reception from the local authorities. More surprisingly, after spending some time in Khiva and visiting the region's main cities, Fedotov neither encountered Indian traders there, nor did he find any significant stores of Indian commodities. Moreover, the Muscovite emissary's overall assessment of Khiva's capacity to maintain trade with India was somewhat pessimistic:

Merchants from India and Balkh do not come [to Khiva and Urgench], nor do the people of Urgench possess the warehouses to trade with the Indians. . . . And tradesmen of the Russian state should not expect high profits from such a trade. ${ }^{51}$

This assessment by the Muscovite observer should perhaps be treated with a certain amount of scepticism. Yet no less ambiguous statements were voiced by the Khivan ruler himself, Anūsha Khān, during an audience with the same Muscovite envoy:

On June 22nd [1669] he [Fedotov] came before the Khan for answer, whereat the Khan announced . . . that what is written in the letter of His Majesty [the Russian] tsar basing upon the assertion of his [the Khivan] ambassador Paianda [Pulad Muhammad] Ruzumov - as if the people of Urgench possess the storehouses for [maintaining] trade with the Indians, this all what had been voiced by his ambassador while being in Moscow, was false. Therefore he, the Khan, will say the word [to punish Ruzumov accordingly] for the artifice. [The Khan also confessed that] there are not people in his realm who trade camel's wool or Indian merchandise; neither do Indians possess any storehouses here [in Khorezm]. ${ }^{52}$

As becomes evident from this passage, the Khivan ruler admitted that the statements of his own ambassador, announced in Moscow, were pure fiction: there were no storehouses of Indian goods in Khorezm, nor did there exist any trade with India. ${ }^{53}$ The vignette is very revealing, as illustrating a distinctly ambivalent attitude on the part of the Khivan elite. The Khivan ruler's disavowals would not prevent his subsequent ambassadors to Muscovy from repeating the same rhetoric for pushing Muscovy to engage with Central Asia as a conduit to India. ${ }^{54}$ The same was true to an even larger extent of Bukharan diplomats in Moscow.

In 1675, the last year of Aleksey Mikhailovich's reign, the Muscovite authorities undertook yet another attempt to reach the Mughal court. Unlike the preceding missions that had focused on investigation of the Central Asian region as a means of possible passage to India, this embassy was tasked with a more precise goal: to proceed farther within the Mughal realm and thereby establish contact with the court of the emperor Aurangzeb.

Information received from Central Asian envoys was instrumental in the decision to send this embassy, too. For instance, on 2 March 1675, the Bukharan ambassador Haajjjī Farrukh, in a conversation with Artamon Matveev-the Romanovs' grand minister and the head of the Posol'skii Prikaz (in office 1671-78) - touched upon the issue of establishing commercial ties with India: 
And whether there would be [commercial and diplomatic] exchange between His Majesty the Tsar and the Khan of Bukhara, then the Russian goods [such as] cloth (sukno) and red hides (iuft') can be exchanged for [Indian] gems, atlases, lals and other precious Indian goods as well as for silver and gold. And Indian possessions lie nearby to those of Bukhara, [so that] one may reach Balkh in ten days, and yet another ten days [are required to travel] from Balkh to the Indian [city of] Kabul. ${ }^{55}$

Asked whether the Russian mission would pass safely to India through Bukhara and Khiva - an understandable question, given that intraregional conflicts had long been an obstacle for earlier Russian missions through Central Asia ${ }^{56}$ - Hājjī Farrukh offered a more than optimistic response:

The Khans of Khiva, Bukhara, and Balkh are [inherently] the same kin: a sister of the Khivan Anusha-khan is married to the Bukharan Abdulaziz-khan, ${ }^{57}$ the latter's daughter is married to the Khivan [Khan]; the Khan of Balkh is a minor brother of the Khan of Bukhara, thus, they all live in peace. And the Tsar Majesty's envoys, whether to Bukharan Khan or to the Indian Shah, could move back and forth safely. . . . And should the Indian Shah [in response] send his envoys and trading people to His Majesty the Tsar, then his [Bukharan envoy's] sovereign Abdulaziz-khan as well as the latter's relatives, the Khan of Urgench and Khan of Balkh, will ensure the [safe] passage over their territories and also escort them farther [to the borders of Muscovy]. ${ }^{58}$

Encouraged by such statements, the Muscovite authorities equipped another embassy, this time headed by Vasily Daudov. ${ }^{59}$ The mission was instructed to go first to Khiva and Bukhara, in order to convince local rulers to provide safe passage as far as Mughal territory to another member of the embassy, someone called Muhammad Yusuf Kasymov (or Hājjjī Iūsuf, as he appears in diplomatic texts from Central Asia). ${ }^{60}$ The latter was known as a merchant and "a resident of the Bukharan inn in Astrakhan." 61 In his missive to the Khivan and Bukharan rulers, the Russian tsar particularly stressed this point:

And we ask that Mamet [Muhammad] Yusupov [be allowed to advance] to the [court] of His Majesty the Indian Shah without any detention [and] with all due assistance; and that you provide him and his people conveyance and escorts so that he would proceed from your possessions to the Indian state safely and fearlessly. ${ }^{62}$

Muhammad Yusuf Kasymov was entrusted with due credentials, an official letter to the Mughal ruler, and the royal gifts that authorised him to make due contacts to the emperor Aurangzeb. ${ }^{63}$ Once again, however, the endeavour proved anything but straightforward. After crossing the Caspian Sea and passing Mangyshlaq, the envoys entered Khiva in October 1675, where they met Anūsha Khān in December. The meeting was evidently rather a fraught one, little helped when Anūsha took for himself the two best gyrfalcons that the envoys had brought from the Romanov tsar as a gift for the ruler of neighbouring Bukhara. ${ }^{64}$ Once in Bukhara, the ambassadors were treated with considerably more respect, but the Bukharan ruler, 'Abd al-'Azīz Khān, disregarding the assertions of his own envoy in Moscow and the Russian tsar's personal request, refused to provide the carts with which Kasymov might then proceed to India. Nor did he provide due escort. As a result, Kasymov set off from Bukhara "to the Indian realm on hired carts." ${ }^{65}$ Kasymov himself later acknowledged that he was able to proceed 
through the Central Asian principalities only by dint of valuable gifts presented to the rulers and courtiers in Khiva, Bukhara, and Balkh. Otherwise, he stated, he and all his people alike "would be plundered, killed but never allowed to reach India." ${ }^{\circ 6} \mathrm{He}$ managed to reach Balkh, and after passing through the Hindukush in the fall of 1676 arrived in Kabul. ${ }^{67}$ It was in these circumstances that, after repeated attempts, the first Romanov diplomatic mission succeeded in reaching Mughal territory.

A governor of Kabul, named as Mekremet Khan (evidently, Mukarram Khān Mir Ishāq) ${ }^{68}$ sent a missive to the royal court in Shahjahanabad about the Russian envoy's arrival. But the reply of the emperor Aurangzeb was barely consistent with the Muscovite officials' expectations. The emperor did not deign to meet with the Russian ambassador, arguing that no relations between the two courts had existed up until the present, and that there was thus no need to initiate them now:

And you, a governor of Kabul, have written to me, to the great Indian Sovereign, that an ambassador had come next to you from the Russian state, and now he [intends] to go before us. . . . Upon this report, my order to you, the Khan of Kabul, is the following: never before have the Russian state's envoys arrived to our Indian state. So it is now: you must send him back to the Russian state [providing him] with [our] royal warrant and [proper] gifts, so that he can go intact back from your [place] to the Russian state. Also, we order you to give to the ambassador an allowance of 2,000 rupees from the treasury and then let him to go. ${ }^{69}$

Mukarram Khān conveyed the order of the Mughal emperor to Kasymov in a more outright fashion:

Since ancient times, since the time of his ancestor Temur Aksak, for several hundred years until nowadays no ambassador or envoy has come from the Russian state to India, [to] his Royal Majesty, to the Indian Shah. . . [it happened] because the Russian state is far distant from India. . . . It is well known, however, that the Russian tsar is now sending his envoys to the Indian Shah seeking wealth only, and not for [any] other reasons; furthermore, [since] the Russian faith is different, it is inappropriate for them, as Muslims, to keep up friendship with the Christians. ${ }^{70}$

Not only did the governor claim that Muscovy's decision to send an envoy was motivated simply by greed, but he also stated that the gifts Kasymov brought were so meagre that "even the lackeys would not buy them." After a number of further humiliations, Kasymov sold all the gifts on the cheap and in early 1678 returned to Moscow. ${ }^{71}$ In these inglorious circumstances, then, the Romanovs' first contact with the Mughal court came to pass.

It was not until twenty years later that Russian envoys ultimately reached the muchdesired court of the emperor Aurangzeb. This would happen in 1694-at the outset of Peter I's reign — when the next Muscovite envoy, a merchant named Semen Malenkov (Malenkii), was accepted at Aurangzeb's military camp in the city of Burhanpur. He was granted a royal firman on behalf of Aurangzeb, which conferred upon him the privilege of being able to trade freely within the Mughal realm. ${ }^{72}$ Yet, Semen Malenkii's route to India was not through Central Asia, as one might have expected, but through the Safavid realm, through Isfahan to Bandar Abbas and thence by sea to Port Surat 
and on to the imperial centres. ${ }^{73}$ Thus, it seemed, a passage to India through Central Asia was not destined to unfold. Yet this would not be end of the story: for two more centuries, the idea of a mythical path to India through Central Asia would continue to excite the minds of the Russian elites.

\section{Rationale}

It becomes evident that throughout most of the seventeenth century, Central Asian elites, whether in Khiva or in Bukhara, sought to utilise for their own purposes Muscovy's growing interest in establishing direct commercial and diplomatic ties with the Mughal court. Bidding their envoys to convey to Muscovite officials assurances about the region's convenience for maintaining trade and diplomatic conduits to India and to express their eagerness to provide due assistance, these Central Asian elites nevertheless remained distinctly reluctant to back up their words with actions. Their statements seem, then, to have served as a purely rhetorical device with which to secure recognition in Muscovy for their own diplomatic and mercantile missions. A question, then, arises: what was the rationale behind such diplomatic pursuits?

Diplomatic missions have been broadly recognised as part and parcel of a larger commercial enterprise. As Erika Monahan has noted of the early modern world, "where there was diplomacy, there was [trade] exchange."74 The diplomatic texts under review provide strong evidence that nearly every diplomatic mission from Central Asia to Muscovy was accompanied by a significant quantity of merchandise intended for trade, as well as a group of merchants. ${ }^{75}$ The documents also indicate that Khivan and Bukharan envoys, while in Muscovy, prioritised short-term commercial success over the fulfilment of diplomatic procedures. Moreover, it becomes evident that the envoys themselves were actively involved in different commercial operations both as agents of their patrons and on their own behalf. It happened, for example, that after arriving in Astrakhan, Khivan envoys refused to proceed farther to Moscow for an audience with the Russian autocrat until they were able to sort out, there on the spot, authorisation to travel also for the Khivan merchants who arrived alongside them. ${ }^{76}$

A number of individuals who arrived in Russian territory under the embassy umbrella enjoyed various tax privileges conferred upon them not only in the port of Astrakhan, but also in other Muscovite cities, including Kazan, Nizhny Novgorod, and Moscow. It was common practice for the Muscovite authorities to provide travel allowances and accommodation for all embassy members along the Volga from Astrakhan to Moscow (a journey lasting up to eight months), together with a security escort and so-called feeding money (kormovye den'gi), paid out from the treasury to each member of the embassy over the entire sojourn within Muscovy. ${ }^{77}$ Thus, we are talking about quite sizeable benefits for those individuals and groups whose commercial interests had been represented by the embassies.

There is another observation worth considering here: namely, that references by Khivan and Bukharan diplomats, both in diplomatic correspondence and through direct 
interpersonal contacts, to the inviting prospect of a Central Asian route to India became increasingly common after 1667, that is, after the adoption of the New Commercial Code in Muscovy. This legislation imposed protectionist restrictions on foreign merchants in Russia. Not only did it stipulate taxes for commodities brought by foreign merchants to the port cities, such as Astrakhan, but it also levied additional dues in the case of their transportation farther inland. ${ }^{78}$ According to some authors, adoption of the new trade regulation by Muscovite authorities had a negative effect, especially at first, on the Central Asian merchants and commercial groups. ${ }^{79}$ Although the letter of the code was clear about this, nevertheless in practice the arrival of every embassy, whether from Bukhara or Khiva, set a precedent. As soon as they reached Astrakhan or Tobol'sk, Khivan and Bukharan envoys appealed to the Muscovite authorities, requesting exemption from customs duty on their imported possessions, in the interest, they claimed, of "maintaining friendship, just as it used to be from ancient times." 80 This, in turn, brought about extensive correspondence among various agencies, from Astrakhan to Moscow, which usually resulted in the issuing of a separate edict from the tsar, granting tax exemptions on the commodities brought by the embassy "for the sake of maintaining good relations." 81

While in Moscow in 1673, for instance, Palvan (Pahlavān) Quli Bek, an envoy of Anūsha Khān, submitted a handful of petitions to the Tsar Aleksey Mikhailovich, requesting reimbursement of the dues that had been levied from his commodities upon his arrival to Astrakhan as well as asking permission for fulfilment of various commercial operations within Muscovy. ${ }^{82}$ In doing so, the Khivan emissary especially emphasised the fact that in return the "Russian envoys, merchants and whatever trading people" who come to Khiva will be allowed to travel farther, to "Balkh, Kabul, Lagiandur [Lahor], right up to the Indian State." ${ }^{, 83}$ In response, the Russian authorities not only ordered the full reimbursement of levied dues, but also granted Palvan Quli exclusive commercial privileges, for instance on purchasing "for the sake of the Khivan khan and himself" a number of "forbidden" commodities (i.e., those that were prohibited for export), such as gyrfalcons, Kalmyk bondservants, and wine. ${ }^{84}$ Most importantly, however, the Khivan envoy was granted the unprecedented right to transport Persian raw silk from Astrakhan to Moscow and sell this merchandise at retail at the Russian capital $^{85}$ a monopoly that only few years earlier had been bestowed exclusively to the network of Julfa Armenians. ${ }^{86}$

Similar diplomatic manoeuvres may be observed in the case of Hājjī Farrukh, the aforementioned Bukharan 'Abd al-'Azīz Khān's envoy to Muscovy in 1673. During his conversation with the chief Muscovite diplomat Artemon Matveev, the envoy outlined in similar manner the prospects of Russian trade relations with India through Bukhara, Balkh, and Khiva. After drawing such a promising picture, the Bukharan diplomat proceeded to the requests, asking for reimbursement of dues levied earlier by authorities in the border city of Tobol'sk. He also stated that the trading people and envoys "who arrive with great number of Bukharan goods" in the Siberian city of Tobol'sk had not been allowed by the local authorities to proceed farther to Muscovy, and asked his interlocutor to facilitate their passage. ${ }^{87}$ 
We thus have clear evidence that airy references to a passage to India were a sort of bargaining chip employed by Central Asian diplomats to help them to secure tax incentives and other privileges for their diplomatic and mercantile missions to Muscovy. Although this helps explain the rationale behind invoking this rhetorical ploy, it provides little clue about why the Central Asian elites were so reluctant (if not indeed downright hostile) towards opening Central Asia up to Russian agents. After all, it would seem, any practical initiatives undertaken in this direction might have been useful in developing long-distance communications and commercial exchange.

It is broadly recognised that Bukhara and Khiva benefitted from the delivery not only of local goods but also of various commodities from neighbouring countries. Yet little is known about the scale of this trade, and we rely mainly on piecemeal information. Details from the correspondence between the governor (voevoda) of Samara and the authorities in Moscow reveal that in 1614 nearly three hundred Bukharan and Khivan merchants travelled together to Samara, from whence they proceeded on to Kazan. ${ }^{88}$ This, obviously, was not an incidental phenomenon. Similar indications may be found throughout the entire seventeenth century. In 1640, for instance, a Bukharan ambassador known as Qazian arrived at the city of Tobol'sk "with a retinue of two hundred people, and a caravan of one hundred camels laden with goods." ${ }^{89}$ In 1669 a Bukharan envoy to Muscovy, Nazar Muhammad, was attacked by bandits on the Yaik (Ural) River and robbed of goods worth as much as 200,000 rubles. ${ }^{90}$ Many of the commodities brought by Central Asian merchants to the Muscovite markets were of Indian origin. ${ }^{91}$ It comes as no surprise then that Khivan and Bukharan merchants, as well as the ruling elites associated with them, did not intend to lose such a lucrative source of advantage. They were determined to prevent Russia from proceeding with a policy of "eliminat[ing] Central Asian middlemen in Eurasian trade, roles that Bukharan merchants had held for

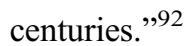

Meanwhile, no less important was Central Asian participation in "informal" trade. Trading so-called human commodities was a crucial part of this. The archive of the Posol'skii Prikaz contains a significant number of interviews with Russian subjects who had been released from slavery. Many of these accounts recall a common story: being captured in different parts of Muscovy by Kalmyks, Bashkirs, or Crimean Tatars, these people were sold out to Khiva and farther in various directions as far as India. ${ }^{93}$ Though the assessment of the trade's value given by former slaves may look something of an overestimation ("And [the total amount] of [Russian] captives in Urgench, Bukhara and Balkh is no less than twenty thousand or so"), ${ }^{94}$ we may note other, more plausible evidence. Pazukhin, a Russian envoy to Bukhara, who spent as long as sixteen months in the city in 1670-71, reported that about one hundred fifty Russian slaves were to be found in the personal possession of the Bukharan khan alone. ${ }^{95}$ Yet, he continued, "the most part of the Russian captives had been held in Khiva wherefrom they were sold by Khivans to India and other distant cities as well as to the Qizilbash [lands]." Khiva was not merely a transit hub of this wide-scale commerce, however. ${ }^{96}$ According to the aforementioned Pazukhin, Khivan agents frequently travelled to "the uluses of Kalmyks and of Bashkirs where, staying for long," they 
encouraged the tribal groups to capture as many people as possible. ${ }^{97}$ While advancing through Kalmyk uluses, the same envoy personally observed a group of two hundred Russian captives who had been taken by Khivan agents to Khwārazm.

Not surprisingly, the various groups in Khiva and Bukhara who had long benefitted from commerce with Muscovy were concerned to maintain such prerogatives. On the one hand, they sought to utilise the authorities in Moscow, and on the other, they tried to keep control of, and derive benefit from, this kind of non-approved hybrid trade. Any degree of institutionalising relations with Russia, and enabling Russia to establish formal influence in the region, might pose a threat to these patterns, and limit their scope for utilising and benefiting from those resources. Central Asian elites were highly motivated both to advertise and to protect their coveted role as "middlemen" in early modern Eurasian trade.

But to explain this phenomenon only in economic terms is to observe only one side of the coin, and risks situating the commercial environments of Khiva and Bukhara in an isolated space detached from broader regional dynamics. I suggest that Central Asian diplomatic engagement with Russia was not so much a single comprehensive strategy as a repertoire of tactics and initiatives that local groups implemented in response to evershifting local circumstances. A final vignette may serve as an eloquent illustration of this point. The incident in question occurred in 1676 during the Russian envoy Vasily Daudov's visit to Khiva. Prior to Daudov's dispatch, in 1675, the Khivan ambassador Abdurrahim (Abraim) Asvebekov had arrived in Moscow. ${ }^{98}$ The ambassador handed over to the Russian tsar a missive from his patron, Anūsha Khān. Amidst the rather formulaic phrasings employed in the missive, one detail stands out in particular: The Khivan khan proposed that the Russian authorities should construct a fortress on the bank of the Caspian Sea on the Mangyshlaq Peninsula. ${ }^{99}$ Anūsha Khān especially emphasised that this enterprise would bring about the "arrival of trading people from Bukhara, Balkh and India with their goods," and that it would enable "great exchange of commodities [with the people] from Balkh and India on the spot."100 Yet despite this rhetoric, when the Romanov envoy Vasily Daudov visited Khiva, the local ruler purposefully avoided the question of constructing a fortress. Only after Daudov's departure back to Astrakhan was one of the Russian envoy's men, a certain Miron, who was still in Khiva, invited back to see Anūsha Khān. During the meeting, the Khivan ruler asked Miron to convey the following "secret words" to Daudov. The khan expressed eagerness for a fortress to be built, but he had been unable to raise the matter directly to Daudov during his formal reception because of the presence on that occasion of numerous bystanders from among Uzbeks and Turkmens. ${ }^{101}$

This episode clearly encapsulates that ambivalence which was so central to Khivan diplomacy - an ambivalence of which we have already encountered numerous other examples. Furthermore, the episode opens a window on the highly complex picture of power relations in early modern Central Asia. It depicts Khivan ruling circles not as a homogenous group, but as conglomerates of individuals prioritising their own strategies in accordance with other regional actors. 
To make sense of Khivan behaviour, it is worth considering these actors vis-à-vis the different groups of Turkmens of Mangyshlaq or Kalmyks who tried to assert themselves not merely as associates, but rather as autonomous stakeholders in trade relations between Central Asia and Muscovite Russia. ${ }^{102}$ All of these groups had been very sensitive to any attempts (whether real or putative) to infringe upon their interests. Muscovite envoy Vasily Daudov reported that upon his arrival in Mangyshlaq he had been immediately approached by the one of the leaders of the local Turkmen clan who appeared to be very concerned at rumours of Muscovite-Khivan negotiations about constructing a fortress in the region. ${ }^{103}$

There can be little doubt that various groups in Khiva had been greatly dependent on trade with Muscovy. The diplomatic texts under study allow us to discern various groups in Khiva who had been closely related to Turkmens or Kalmyks, by dint of which they sought to secure passage and transportation to and fro or, as was shown above, to supply Russian captives. Given their limited political and economic resources, the Khivan authorities were hardly able to design a more fully formed mercantile system on the model of the Mughals or Safavids. ${ }^{104}$ Such provisions were beyond the grasp of Central Asian rulers, who instead sought to exploit those limited resources they possessed, and to capitalise on their own marginality.

With this all in mind, I am reluctant to depict the officials of Muscovy merely as simpletons, stumbling, time and again, upon the same trick, and whose naivety was so fruitfully utilised by Khivan or Bukharan circles. It is striking, however, when we take a closer look at the documents of Posol'skii Prikaz related to India, that one comes across the same set of questions, which continued to engage the attention of Muscovite officials throughout the seventeenth century: questions about the Mughal emperor's titulature, his religious affiliation, his place of residence, his preferred choice of gifts, and the language with which one should address him. The fact that such elementary questions remained preeminent matters of concern many decades after the Russians first attempted to establish relations with Mughal India suggests just how little had been achieved by Russian diplomatic initiatives.

In the instance of the chancellery practices of the seventeenth-century Muscovite Posol'skii Prikaz, one can observe a well-developed bureaucratic apparatus that allowed the emergent Russian state to record, preserve, and duplicate an extensive paper trail. Yet bureaucratic selectivity, the peculiarity of clerical jargon with its emphasis on recording formal procedural issues above all else, and the idea of precedent as a cornerstone of decision-making processes together limited the effectiveness of this solid body of knowledge. ${ }^{105}$ Such ineffectiveness was clearly on display when Peter I, disregarding nearly all informed opinion, ${ }^{106}$ chose to throw several thousand people into a hazardous expedition on the basis of hearsay and rumour about there being gold for the taking and an easily navigable fluvial rote to India - rumours which, as noted by Stephen Dale, had already been rejected by the Muscovite officials by the end of the seventeenth century. ${ }^{107}$

Perhaps even more surprisingly, however, such faith in rumour seems to have survived even after the reign of Peter $\mathrm{I}^{108}$ when, as conventional wisdom tries to assure us, state apparatus, record-keeping systems, and diplomatic techniques underwent a significant 
transformation. ${ }^{109}$ In early 1732 , for instance, a little more than a decade after BekovichCherkassky's disastrous endeavour, yet another caravan-cum-expedition in search of gold was dispatched to Khiva, headed this time by Colonel Johann Gustav Garber. Duke Aleksey Cherkassky, one of the leading Russian statesman of the time and principal initiator of the enterprise, instructed the head of the caravan, "to investigate the river that reportedly flowed from the Aral Lake to the Caspian Sea; and . . should be this true [to find out] how firm are the dams and embankments [that prevent water from erstwhile flow]." Furthermore, "by all possible means to investigate about the passage for the Russian merchantry to India, to those places where are the gold and gems to be found." 110 The fate of this expedition was barely less gruesome than that of BekovichCherkassky's. ${ }^{111}$

Similarly expressed diplomatic aims and purposes can be observed a few decades later. In 1801 Count Valerian Zubov, a top-ranking official at the court of Russian Emperor Alexander I (r. 1801-25), brought to the fore a new project on the revitalisation of commerce and trade with the Asian states, wherein India occupied a special place. ${ }^{112}$ One finds in Zubov's proposal a bricolage of the same stereotypes and rhetoric, such as how, since the time of antiquity, commodities from Hindustan and western China have been delivered to the Caspian littoral by fluvial routes along the Amu Darya. Yet most revealing, perhaps, for our purposes, was the fact that Zubov found nothing better than to acknowledge the absence of any reliable data about convenient routes that may have connected Russia with India. ${ }^{113}$ It seems that, as in earlier centuries, after decades of pursuing this goal, notwithstanding manifold encounters and collected expertise, India continued to be perceived in the upper echelons of the Russian political mind as a prize that was there for the taking, if one only knew how.

\section{Acknowledgements}

This essay originates from the conference Beyond the Islamic Chancery (Vienna 2018); I would like to thank Paolo Sartori and James Pickett for the gracious invitation and constant encouragement. Thanks also to Thomas Welsford and two anonymous Itinerario reviewers for their constructive comments and feedback. Any errors contained herein are my own.

\section{Bibliography}

\section{Unpublished Primary Sources}

Gosudarstvennyi Arkhiv Astrakhanskoi Oblasti (State Archive of the Astrakhan Province) [GAAO].

- Fond 394-Astrakhanskaia Gubernskaia Uprava (Astrakhan Provincial Chancellery), op. 1,

d. 1570 (Delo o proezde cherez Astrakhan' Khivinskogo Khana Nurally-Kutlumamet Khodzhieva).

Nauchnyi i Istoricheskii Arkhiv Sankt-Peterburgskogo Instituta Istorii RAN (Scientific and Historical Archive of Saint-Petersburg Institute of History, Russian Academy of Sciences) [NIAII RAN]. 
-Fond 113-Russkoe istoricheskoe obshchestvo (Russian Historical Society), op. 1, d. 93 (Posol'skie knigi snoshenii Rossii s Bukharoiu. Knigi 1,2,3); d. 94 (Posol'skie knigi snoshenii Rossii s Khivoiu. Knigi 1,2,3).

Rossiiskii Gosudarstvennyi Arkhiv Drevnikh Aktov (Russian State Archive of Ancient Acts) [RGADA].

-Fond 134-Snocheniia Rossii s Khivoiu (Russian Relations with Khiva) op. 1, d. 4 (Vypiska o byvshikh v Rossii Khivinskikh posol'stvakh s 1616 po 1743 god).

-Fond 56- Snocheniia Rossii s Indeiu (Russian Relations with India), op. 2, god 1696, d. 5 (List blizhnego Khana dannyi po prikazy Indeiskogo vladetelia byvshemu v Indii Rossiiskomu kupchine Semenu Malen'komu).

-Fond 397-Komissiia o kommertsii i poshlinakh (Commerce and Duties Commission), op. 1, d. 314 (Predlozhenie o Bukharskom torge Kniazia Alekseia Cherkasskogo, podpisannoe sobstvennoiu Eia Imperatorkogo Velichestva rukoiu).

Rossiiskii Gosudarvennyi Istoricheskii Aposorkhiv (Russian State Historical Archive) [RGIA].

-Fond 1374-Kantseliariia General-prokurora (Chancellery of the Attorney General), op.2, d. 2399a (Perepiska po povodu mer dlia razvitiia torgovykh snochenii s Indiei, Bukharoiu $i$ Khivoiu).

\section{Published Primary Sources}

Anon. "Opisanie chego radi nevozmozhno ot Arkhangel'skogo gorodka morem prokhoditi v Kitaiskoe gosudarstvo i ottole $\mathrm{k}$ vostochnoi Indii." In Chteniia v Imperatorskom obshchestve istorii i drevnostei rossiiskikh, book 4, ed. E. V. Barsov, 13-4. Moscow: n.p., 1893.

Antonova, K. A., et al., eds. Russko-indiiskie otnosheniia v XVII v. Sbornik dokumentov. Moscow: Izdatel'stvo vostochnoi literatury, 1958.

Belokurov, S. A., ed. "Dela Tainogo Prikaza, Kniga pervaia." In Russkaia istoricheskaia biblioteka, vol. 21, 850. St. Petersburg: Tipografiia V. Balasheva, 1907.

Bychkov, A. F. ed. Materialy voenno-uchebnogo arkhiva Glavnogo shtaba, vol. 1. St. Petersburg: Pechatnia V. I. Golovina, 1871.

Dolgov, S. O. "Vedomost' o Kitaiskoi zemle i o glubokoi Indei" (Introduction and commentaries by S. O. Dolgov). In Pamiatniki drevnei pis'mennosti $i$ iskusstva, vol. 133, 14-35. St. Petersburg, 1899.

Kobenko, Dmitry. Nakaz Tsarya Alekseia Mikhailovicha Makhmetu Iusupu Kasimovu, poslannomu v 1675 godu k Velikomu Mogolu Aurenzebu. St. Petersburg: Tipografiia V.Kirshbauma, 1884.

Kulmamatov, D. S., et al., eds. Stateinyi spisok posol'stva Savina Gorokhova i Anisima Gribova v Khivy i Bukharu v $1641 \mathrm{~g}$. Moscow: MGPU im. V. I. Lenina, 1994.

Navvāb Șamșām ud-Daula Shāh Navāz Khān and 'Abd ul-Hayy: The Maāthir-ul-Umarāa, Being Biographies of the Muhammadan and Hindu Officers of the Timurid Sovereigns of India from 1500 to about 1780 AD. Trans. into English by Henry Beveridge, revised, annotated, and completed by Baini Parshad. 2 vols. and index. Kolkata: Asiatic Society, 1952, repr. 2003.

Samoilovich, A. N., ed. Materialy po istorii Uzbekskoi, Tadzhikskoi i Turkmenskoi SSR. Chast' I. Torgovlia s Moskovskim gosudarstvom i mezhdunarodnoe polozhenie Srednei Azii v XVIXVII $v v$. Leningrad: Izdatel'stvo AN SSSR, 1932. [MIUTT]

Skachkov, P. E. "Vedomost' o Kitaiskoi zemle i o glubokoi Indei." In Strany i narody Vostoka. Geografiia, etnografiia, istoriia, ed. V. V. Struve and A. V. Korolev, pt. 2, 212-9. Moscow: Izdatel'stvo vostochnoi literatury, 1961.

Truvorov, A. N., ed. "Nakaz Pazukhinym, poslannym v Bukharu, Balkh i Iurgench, 1669." In Russkaia istoricheskaia biblioteka, vol. 15, 1-86. St. Petersburg: Tipografiia V. S. Balasheva: 1894.

Veselovsky, N. "Posol'stvo v Khivu Ivana Matveeva Fedotova i ego stateinyi spisok prebyvaniia v Khive, 1669-1670.” Turkestanskie vedomosti 20 (25 May 1882): 79. 
Veselovsky, N. "Posol'stvo Mikhaila Nikiticha Tikhanova." In Trudy Vostochnago Otdeleniia Imperatorskogo Russkago Arkheologicheskago Obshchestva, vol. 21, 151-312. St. Petersburg: Skoropechatnia P. O. Iablonskaga, 1892.

Zubov, V. A. "Obshchee obozrenie torgovli s Azeiiu (Zapiska sostavlennaia grafom V. A. Zubovym).” Russkii arkhiv 1 (1873): 879-94.

\section{Secondary Sources}

Alam, Muzaffar. "Trade, State Policy and Regional Change: Aspects of Mughal-Uzbek Commercial Relations, c. 1550-1750." Journal of Economic and Social History of the Orient 37:3 (1994): 202-27.

Andreev, A. "Khiva i Rossiia v nachale XVIII veka, ili istoriia odnoi nesostoiavsheisia provintsii." In Stolitsy i provintsia, ed. E.V. Anisimov, 259-72. St. Petersburg: Evropeiskii dom, 2013.

. "Ashūr Bek's Letters and Prince A. B. Cherkassky's Mission." Manuscripta Orientalia 22:2 (2016): 9-28.

- "K voprosu o rannem periode biografii Aleksandra Bekovicha-Cherkasskogo." In Arkheologiia o etnologiia Severnogo Kavkaza, pt. 2, 132-37. Nal'chik: KBIGI, 2013.

Baikova, N. B. Rol' Srednei Azii v russko-indiiskikh torgovykh sviaziakh (pervaia polovina XVI-vtoraia polovina XVIII v). Tashkent: Nauka, 1964.

Bartol'd, V. Istoriia izucheniia Vostoka v Evrope $i$ Rossii. Leningrad: Gosudarstvennaia uchebno-prakticheskaia shkola-tipografiia im, Alekseeva, 1925.

Becker, S. Russia's Protectorate in Central Asia: Bukhara and Khiva, 1865-1924. Cambridge, Mass.: Harvard University Press, 1968.

Belokurov, S. A. O posol'skom prikaze. Moscow: [n.p.], 1906.

Bohlen, Avis. "Changes in Russian diplomacy under Peter the Great." Cahiers du Monde Russe 7:3 (1966): 341-58.

Brezneva, S. N. "Popytki ustanovleniia pervykh kul'turnykh i torgovykh kontaktov Rossii s khanstvami Srednei Azii v XVIII veke." Vestnik Saratovskogo gosudarstvennogo tekhnischeskogo universiteta 60:4 (2011): 289-95.

Burton, Audrey. The Bukharans: A Dynastic, Diplomatic and Commercial History, 1550-1702. New York: St. Martin's Press, 1997.

Bushkovitch, Pavel. "Peter and the Seventeenth Century." In Modernizing Muscovy: Reform and Social Changes in Seventeenth-Century Russia, ed. Jarmo Kotilaine and Marshall Poe, 46176. London-New York: Routledge Curzon, 2004.

Chuloshnikov, A. "Torgovlia Moskovskogo gosudarstva s Srednei Aziei v XVI-XVII vekakh.” In MIUTT, ed. A. N. Samoilovich, 61-8. Leningrad: Izdatel'stvo AN SSSR, 1932.

Dale, Stephan Frederic. Indian Merchants and Eurasian Trade, 1600-1750. Cambridge: Cambridge University Press, 1994.

D.L. “Avtobiografiia stol'nika V. A. Daudova, XVII veka.” Russkii arkhiv 2:5 (1889): 5-20.

Dunning, Chester S. L. A Short History of Russia's First Civil War: The Time of Troubles and the Founding of the Romanov Dynasty. University Park: Pennsylvania State University Press, 2004.

Eden, Jeff. Slavery and Empire in Central Asia. New York: Cambridge University Press, 2018.

Floor, Willem. The Economy of Safavid Persia. Wiesbaden: Reichert, 2000.

Foltz, Richard. "The Mughal Occupation of Balkh, 1646-1647." Journal of Islamic Studies 7:1 (1996): 49-61.

Gol'dberg, N. M. “Russko-indiiskie otnosheniia v XVII v." In Uchenye zapiski Tikhookeanskogo instituta, vol. 2, Indiiskii sbornik, 129-48. Moscow-Leningrad: Izdatel'stvo AN SSSR, 1949.

Gulomov, Kh. Diplomaticheskie otnosheniia gosudarstv Srednei Azii s Rossiei v XVIII-pervoi polovine XIX veka. Tashkent: Fan, 2005. 
Hennings, Jan. Russia and Courtly Europe: Ritual and the Culture of Diplomacy, 1648-1725. Cambridge: Cambridge University Press, 2016.

Iuldashev, M. Iu. K istorii torgovykh i posol'skikh sviazei Srednei Azii s Rossiei v XVI-XVII vv. Tashkent: Fan, 1964.

Kemp, P. M. Bharat-Rus: An Introduction to Indo-Russian Contacts and Travels from Medieval Times to the October Revolution. Delhi: ISCUS, 1958.

Kemp, P. M. "Early Contacts between India and Russia." Journal of the Indo-Soviet Cultural Society 2:1 (1954): 32-49.

Khodarkovsky, Michael. Where Two Worlds Met: The Russian State and the Kalmyk Nomads, 1600-1771. Ithaca, N.Y.: Cornell University Press, 1992.

Kotilaine, Jarmo T. Russia's Foreign Trade and Economic Expansion in the Seventeenth Century: Windows on the World. Leiden-Boston: Brill, 2005.

Kozintsev, M. A. "Gramota Khivinskogo khana Shir-gazi tsariu Petru I. Predislovie, publikatsiia, primechaniia." Pismennye pamiatniki Vostoka 15:2 (2018): 5-24.

Kudriashov, K. "Zubov, graf Valerian Aleksandrovich.” In Russkii biograficheskii slovar', vol. 7, ed. E. S. Shumigorsky and M. G. Kurdiumov, 514-22. Petrograd: Tipografiia glavnogo upravleniia udelov, 1916.

Létolle, René. "Les expéditions de Bekovitch-Tcherkassy en Turkestan (1714-1717) et le début de l'infiltration russe en Asie centrale." Cahiers d'Asie centrale 5:6 (1998): 259-84.

Levi, Scott C. "Hindus Beyond the Hindu Kush: Indians in the Central Asian Slave Trade." Journal of the Royal Asiatic Society 12:3 (2002): 277-88.

Levi, Scott C. The Indian Diaspora in Central Asia and Its Trade, 1550-1900. Leiden: Brill, 2002.

Malinovsky, A. "Izvestie ob otpravleniiakh v Indiiu rossiiskikh poslannikov, gontsov i kupchin s tovarami i o priezdakh v Rossiiu indeitsev, s 1469 po 1751 god." In Trudy $i$ letopisi Obshchestva istorii $i$ drevnostei Rossiskikh, vol. 7, 121-207. Moscow: Universitetskaia tipografiia, 1837.

Martin, Janet. "The Sixteenth-Century Legacy." In Modernizing Muscovy: Reform and Social Changes in Seventeenth-Century Russia, ed. Jarmo Kotilaine and Marshall Poe, 8-26. London-New York: Routledge Curzon, 2004.

Matthee, Rudi. "Anti-Ottoman Politics and Transit Rights: The Seventeenth-Century Trade in Silk between Safavid Iran and Muscovy." Cahiers du Monde russe 35:4 (1994): 739-61.

- The Politics of Trade in Safavid Iran: Silk for Silver, 1600-1730. Cambridge: Cambridge University Press, 1999.

—. "Rudeness and Revilement: Russian-Iranian Relations in the Mid-Seventeenth Century." Iranian Studies 46:3 (2013): 1-25.

Maxwell, Mary Jane. "Afanasii Nikitin: An Orthodox Russia's Spiritual Voyage in the Dar al-Islam, 1468-1475." Journal of World History 17:3 (2006): 243-66.

Minaev, Ivan. "Russkie pomysly ob Indii v starinu." Zhurnal Ministerstva narodnogo prosveshcheniia 235 (1884): 349-59.

- Svedeniia o stranakh po verkhov'iam Amu-Dar'i. St. Petersburg: Tipografiia V. S. Balasheva, 1879.

Monahan, Erika. The Merchants of Siberia: Trade in Early Modern Eurasia. Ithaca, N.Y.: Cornell University Press, 2016.

Pal'mov, N. N. “Astrakhanskie arkhivy (Obraztsy materialov o natsional'nostiakh)." Zapiski Instituta Vostokovedeniia Akademii nauk SSSR 2:4 (1934): 161-82.

Pankov, A. V. "K istorii torgovli Srednei Azii s Rossiei XVI-XVII vv." In V.V. Bartol'du, Turkestanskie druz'ia, ucheniki i pochitateli, 20-47. Tashkent: Obshchestvo dlia izucheniia Tadzhikistana i iranskikh narodnostei za ego predelami, 1927.

Penrose, G. L. "Inner Asian Influence on the Earliest Russo-Chinese Trade and Diplomatic Contacts." Russian History 1:4 (1992): 361-92. 
Pochekaev, R. "Pamiat' ob ekspeditsii A. Bekovicha-Cherkasskogo v russko-khivinskikh otnosheniakh XVIII-XIX vv." Novoe Proshloe: The New Past 1 (2016): 132-44.

Poujol, Catherine. "Les Voyageurs Russes et l'Asie Centrale: Naissance et Declin de Deux Mythes, les Réserves d'Or et la Voie Vers l'Inde." Central Asian Survey 4:3 (1985): 59-73.

Poullada, Peter S. Russian-Turkmen Encounters: The Caspian Frontier before the Great Game. London-New York: I. B. Tauris, 2017.

Preobrazhensky, A. A. "Iz istorii ontnoshenii russkogo gosudarstva so Srednei Aziei v XVII v. (Dva posol'stva torgovogo cheloveka Anisima Gribova)." Istoricheskie zapiski 36 (1951): 268-86.

Rogozhin, N. M. Posol'skii prikaz: kolybel' rossiiskoi diplomatii. Moscow: Mezhdunarodnye otnosheniia, 2003.

Romaniello, Mathew. “'In Friendship and Love': Russian Travellers to Muslim Lands in the Early Modern Era." Historical Yearbook of Nicolae Iorga History Institute of the Roman Academy 6 (2009): 111-22.

Selifontov, N. “Ocherk sluzhebnoi deiatel'nosti i domashnei zhizni stol'nika i voevody XVII stoletiia, Vasil'ia Aleksandrovicha Daudova." In Letopis' zaniatii Arkheographicheskoi komissii [1867-1870], pt. 5, 1-41. St. Petersburg: Tipografiia Zamyslovskago i Bobyleva: 1871.

Sela, Ron. "Prescribing the Boundaries of Knowledge: Seventeenth-Century Russian Diplomatic Missions to Central Asia." In Writing Travel in Central Asian History, ed. Nile Green, 69-88. Bloomington: Indiana University Press, 2014.

Schimmelpenninck van der Oye, David. "Paul's Great Game: Russia's Plan to Invade British India." Central Asian Survey 33:2, 143-52.

Soimonov, F. S. Opisanie Kaspiiskogo moria i chinennykh na onom rossiiskikh zavoevanii. St. Petersburg: Imperatorskaia Akademiia nauk, 1763.

Tambs, Lewis A. “Anglo-Russian Enterprises against Hispanic South America, 1732-1737.” The Slavonic and East European Review 48:112 (1970): 357-72.

Veselovsky, N. "Priem v Rossii i otpusk sredneaziatskikh poslov v XVII i XVIII stoletiiakh." Zhurnal narodnogo prosveshcheniia, vol. 234, 68-105. St. Petersburg: Tipografiia V.S. Balasheva, 1884.

Ulianitsky, V. A. Snosheniia Rossii s Srednei Azieiu i Indeiu v XVI-XVII vv. Po dokumentam Moskovskogo Glavnogo Arkhiva Ministerstva Inostrannykh Del. Moscow: Universitetskaia tipografiia, 1889.

Wanner, Michal. "Alexander Bekovich Cherkassky's Campaign to Central Asia and India in 17141717." Öt Kontinens 1 (2014): 9-32.

Yevstratyev, O. "Chronological Dating of the Duchy of Courland's Colonial Policy." Latvijas Vēstures Institūta Žurnāls 108:3 (2018): 34-72.

Zhukovsky, S. V. Snosheniia Rossii s Bukharoi i Khivoi za poslednee trekhsotletie. Petrograd: n.p., 1915.

\section{Notes}

* Ulfat Abdurasulov is a Petra Kappert Fellow at the Centre for the Study of Manuscript Cultures, University of Hamburg.

1 On his biography, see Andreev, "K voprosu o rannem periode biografii," 132-8.

2 See, Bychkov, Materialy voenno-uchebnogo arkhiva, 213-5; Soimonov, Opisanie Kaspiiskogo moria, 9-12.

3 In the current essay the terms "Khorezm" and "Khivan Khanate" are used as synonyms. The name "Khanate of Khiva" was adopted in the eighteenth century from European (mostly Russian) literature for the state formation located in the lower stream of the Amu Darya on the territory of the Khorezmian oases. In seventeenthcentury Muscovite diplomatic texts, the 
khanate was usually identified as "Iurgenskie zemli" or "Khivinskie zemli," i.e., "lands of Urgench" or "lands of Khiva," in reference to the region's two main cities. The city of Urgench, in the northwestern part of the oasis, had been the capital city of the region during most of the medieval period, but following the change of course of the Amu Darya in the early seventeenth century, medieval Urgench was gradually abandoned, and its name was transferred to a newly established city in South Khorezm; the older medieval settlement, meanwhile, was thereafter known in the sources by the name of Kuhna (Old) Urgench. From the seventeenth century, the city of Khiva started to occupy the dominant role in the political life of Khorezm.

4 For the details on the expedition, see, Létolle, "Les expéditions de BekovitchTcherkassy," 261-84; Gulomov, Diplomaticheskie otnosheniia, 52-62; Andreev, "Khiva i Rossia," 266-72; idem, "Ashūr Bek's Letters," 9-28; Wanner, "Alexander Bekovich Cherkassky'a Campaign," 12-31.

5 According to Catherine Poujol, the fate of Bekovich-Cherkassky's expedition had a "traumatic" effect for the Russian state and significantly reinforced the Russian sense of "impenetrability" of Muslim oases of Central Asia: see her "Les Voyageurs Russes et l'Asie Centrale," 59-73. See also Pochekaev, "Pamiat' ob ekspeditsii," 132-44.

6 This is not to say that commercial and diplomatic liaisons between Muscovy and Central Asian principalities have escaped the attention of previous scholarship. Indeed, from the second half of the nineteenth century several generations of scholars have addressed these issues. But such scholars have generally reflected the same topoi, tending to depictexplicitly or otherwise - pre-Petrine diplomacy as an assemblage of sporadic and clumsy encounters, full of diplomatic failures. Moreover, many of these basic tropes permeate the literature to the present day; see for instance Veselovsky, "Priem v Rossii i otpusk," 81; Zhukovsky, Snosheniia Rossii s Bukharoi i Khivoi, 47-8; Becker, Russia's Protectorate, 12; Gulomov, Diplomaticheskie otnosheniia, 46; Brezneva, "Popytki ustanovleniia," 289-95; Pochekaev, "Pamiat' ob ekspeditsii," 134; Kozintsev, "Gramota Khivinskogo khana Shir-gazi," 5.

7 Burton, The Bukharans, 65.

8 Dunning, A Short History of Russia's First Civil War. On the early development of Russia's history, see also Martin, "The Sixteenth-Century Legacy,” 8-26.

9 Kotilaine, Russia's Foreign Trade, 59, 448; Matthee, "Anti-Ottoman Politics and Transit Rights," 742.

10 Monahan, The Merchants of Siberia, 99-101; Poullada, Russian-Turkmen Encounters, 8.

11 Kotilaine, Russia's Foreign Trade, 446.

12 Ibid., 467.

13 Burton, The Bukharans, 463, 500-1; Dale, Indian Merchants, 84-5.

14 Monahan, The Merchants of Siberia, 53.

15 Kotilaine, Russia's Foreign Trade, 8; Monahan, The Merchants of Siberia, 60.

16 Dale, Indian Merchants, 83.

17 Romaniello, "In Friendship and Love," 115-7.

18 Alam, "Trade, State Policy and Regional Change," 208; Levi, The Indian Diaspora, 227-8; Létolle, "Les expéditions de Bekovitch-Tcherkassy," 260.

19 Kemp, Bharat-Rus, 1-13; idem, "Early Contacts between India and Russia," 32-49; Baikova, Rol' Srednei Azii, 14; Minaev, "Russkie pomysly ob Indii," 349-59.

20 On the initial attempts at diplomatic contact between the Tsardom of Russia and India in the sixteenth century, see Bartol'd, Istoriia izucheniia Vostoka, 174-9; Malinovsky, "Izvestie ob otpravleniiakh v Indiiu," 121-4.

21 Samoilovich, MIITT, Letter of the Khān Isfandiyār to Prince Aleksey Mikhailovich, 1641, 165-6 (doc.50).

22 On the history of Indian merchants and entrepreneurs' activity in Muscovy in 
the first half of the seventeenth century, see Pal'mov, "Astrakhanskie arkhivy," 161-7; Antonova et al., Russko-indiiskie otnosheniia, 140-6; Dale, Indian Merchants, 87-90.

23 The Posols'kii Prikaz (Foreign Affairs Chancery) was the governmental body of the Muscovy that throughout the seventeenth century (up to 1720) oversaw the dispatch of Russian diplomatic agents abroad, as well as the reception of foreign ambassadors. In the period under discussion, the Foreign Chancery functioned as the locus of all diplomatic exchanges: this institution was where all diplomatic correspondence took place, whether incoming or outgoing, and where relevant information was produced, copied, and preserved; see further, Belokurov, O posol'skom prikaze; Rogozhin, Posol'skii prikaz, 27-71; Hennings, Russia and Courtly Europe, 69-77.

24 Antonova et al., Russko-indiiskie otnosheniia, 141-2 (doc. 66); 143-7 (doc. 68).

25 Letter (gramota) of Tsar Aleksey Mikhailovich to the voevoda of Astrakhan, 20 May 1647, Antonova et al., Russko-indiiskie otnosheniia, 867 (doc. 35). Though one should not overestimate such a directive, since similar orders had been issued by the Muscovite authorities in favour of other foreign mercantile groups, e.g., Julfa Armenians, Bukharans, and Khivans; see Matthee, "The Politics of Trade in Safavid Iran," 192-7.

26 One of the earliest evidences of such attempts is a notebook (tetrad') from 1632 , comprising a variety information about India ( pisano pro Indeiskoe gosudarstvo), see Belokurov, "Dela Tainogo Prikaza," st. 850.

27 An extract from the ambassadorial report (stateinoi spisok) of Aleksey Romachukov, Russian envoy to Persia, 24 October 1637, Antonova et al., Russko-indiiskie otnosheniia, 33-7 (doc. 11); a report of the Russian envoys to Persia F. Narbekov and V. Ushakov, 1655, ibid, 154-5 (doc. 77).

28 See the interviews (rassprosnye rechi) of the Indian merchants, ibid., 189-1 (docs. 108-9)

29 NIAII RAN, f. 113, op.1, d. 93 (Posol'skie knigi snoshenii Rossii $s$ Bukharoiu), 1. 155 ob.

30 Nearly two centuries earlier, in 1471-74, the Russian merchant-traveller Afanasy Nikitin had visited India, and later produced a lengthy account of his travels known as Voyage Beyond Three Seas [Khozhdenie za tri moria Afanasiia Nikitina]. Some historians have pointed out that Nikitin's account found its way into several sixteenth- and seventeenthcentury Russian chronicles; see Maxwell, "Afanasii Nikitin," 243-5. It seems, however, that this was not the case with the diplomatic texts. For all the reliance of the Muscovite diplomatic chancellery on previous precedents, none of the seventeenth-century diplomatic texts relating to India refers to Nikitin's travel experiences. It is safe to conclude that Nikitin's Voyage had little, if any, impact on diplomatic fact-finding in seventeenth-century Russia.

31 NIAII RAN, f. 113, op.1, d. 93 (Posol'skie knigi snoshenii Rossii s Bukharoiu), 11. 202-2 ob.

32 An extract from the ambassadorial report of Russian envoys I. A. Zheliabuzhsky and Iu. Nikiforov, in Antonova et al., Russko-indiiskie otnosheniia, 139-41 (doc. 65).

33 On Courland's colonial policy in the West Indies see further, Tambs, "Anglo-Russian Enterprises," 357-72; Yevstratyev, "Chronological Dating," 34-72.

34 Though various handwritten versions of the text circulated widely among the diplomatic personnel of pre-Petrine Russia, the printed edition was not produced until 1899; see Dolgov, "Vedomost' o Kitaiskoi zemle i o glubokoi Indei," 14-35. For the purpose of our study we addressed the latter edition 
of the text, see Skachkov, "Vedomost' o Kitaiskoi zemle i o glubokoi Indei," 212-9.

35 Skachkov, "Vedomost' o Kitaiskoi zemle i o glubokoi Indei," 219.

36 Anon., "Opisanie," 13-4.

37 On the documents related to this embassy, including the tsar's instructions (nakaz) to Russian envoys as well as the tsar's letters to the Safavid and Mughal rulers, see Antonova et al., Russko-indiiskie otnosheniia, 48-73 (docs. 24-30).

38 On the details of Anisim Gribov's diplomatic mission to Khiva and Bukhara in 1642-43, see Kulmamatov et al., Stateinyi spisok Posol'stva; Burton, The Bukharans, 215-21.

39 An extract from the ambassadorial report of Anisim Gribov, 1646-48; see Antonova et al., Russko-indiiskie otnosheniia, 74-82 (doc. 32).

40 See an extract from the ambassadorial report of the Russian envoys in Persia, S. I. Kozlovsky and I. Zinov'ev (April 1647), in Antonova et al., Russkoindiiskie otnosheniia, 70-3 (doc. 30); for more on this military conflict, see Foltz, "The Mughal Occupation," 49-61.

41 Ibid.; see also, Preobrazhensky, "Iz istorii ontnoshenii," 269-86; Burton, The Bukharans, 242-3.

42 Baikova, Rol's Srednei Azii, 53-4.

43 The embassy was headed by the Russian merchants Rodion Nikitin syn Pushnikov and Ivan Derevensky, who according to Romaniello were chosen for their familiarity with the Indian diaspora community that resided within Muscovy; see Romaniello, "In Friendship and Love," 118.

44 Ulianitsky, Snosheniia Rossii s Srednei Azieiu i Indeiu, 35-7.

45 There were two main routes that had been adopted in the mid-seventeenth century as the main passage for people and commodities between Muscovy and Central Asia. One such route, the so-called Khivan route, ran from the city of
Astrakhan southeastward through Yaitsk (Gur'yev) at the mouth of the Yaik (Ural) River, and reached the Ust-Urt plateau. Thence it skirted the Aral Sea littoral from the northwest and reached the Khorezmian oases. Of no less importance was the trans-Caspian maritime route that connected Astrakhan with the region of Mangyshlaq. It was there the terrestrial stretch of the route across Mangyshlaq and Ust-Urt connected to the northwestern limits of the Khorezm; see Chuloshnikov, "Torgovlia Moskovskogo gosudarstva," 73-6; Burton, The Bukharans, 391-9.

46 Matthee, "Anti-Ottoman Politics," 74950; idem, "Rudeness and Revilement," 7; see also Romaniello, "In Friendship and Love," 7.

47 Penrose, "Inner Asian Influence," 3713.

48 Bartol'd, Istoriia izucheniia Vostoka, 179.

49 Pulad Muhammad Bek (Ruzumov) - an ambassador of Anūsha Khān to the court of Aleksey Mikhailovich in 1667-68; on the details of his embassy, see RGADA, f. 134, op. 1, d. 411. 28-9.

50 The minutes (rassprosnye rechi) of Ruzumov's conversation with Afanasii Ordin-Naschokin, 19 December 1667; see Antonova et al., Russko-indiiskie otnosheniia, 162-3 (doc. 85).

51 Veselovsky, "Posol'stvo v Khivu," 79.

52 Ibid.

53 This is not to say that Fedotov's observation regarding Indian commercial activities necessarily applied to the whole Central Asian region at the period under review. Scott Levi observed that Indians were ubiquitous as merchants and moneylenders in Bukhara throughout the seventeenth century, and later in Khoqand, but appear to have been essentially absent from Khivan markets; see Levi, The Indian Diaspora, 124-50.

54 See, for instance, the letter of Anūsha Khān to the Tsar Aleksey Mikhailovich, 1673, NIAII RAN, f. 113, op.1 d. 94 (Posol'skie knigi snoshenii Rossii $s$ Khivoiu), 11. 40 ob. -41. 
55 Interview of Bukharan envoy Haàjjī Farrukh with the boyar Artamon Matveev, 2 March 1675; see Iuldashev, $K$ istorii torgovykh i posol'skikh sviazei, 88; Antonova et al., Russko-indiiskie otnosheniia, 170-1 (doc. 93).

56 This was the case of Anisim Gribov in 1642, who was unable to advance beyond Isfahan towards Balkh and Bukhara due to military conflict in the region; see Preobrazhensky, "Iz istorii ontnoshenii," 282-3. Later, in 1670-71, another Russian envoy, Boris Pazukhin, reported that while in Bukhara, despite the tsar's instruction to advance farther to Balkh, he had been unable to do so, as "there was a war between Bukhara and Balkh rulers, [therefore] there is no way to and fro, and people have been killed on the roads"; see Truvorov, "Nakaz Pazukhinym," 63. See further on Pazukhin's mission, Burton, The Bukharans, 292-8; Sela, "Prescribing the Boundaries of Knowledge," 80-4.

57 'Abd al-'Azīz Khān-ruler of Bukhara in $1645-81$.

58 NIAII RAN, f. 113, op. 1, d. 93,1. 62. Interestingly enough, a few years earlier, in 1670, yet another Bukharan envoy to Moscow, a certain Mullā Farrukh, also emphasised the fact that traders from Bukhara visit India "incessantly," bringing back with them luxury goods, "precious stones and pearls," and various fabrics. He also unequivocally suggested that Russian merchandise such as sables, fox furs, and walrus tusks would be highly demanded and appreciated on the Indian markets. "Minutes of conversation of the Bukharan envoy Mulla Farrukh, 2 March 1671, Iuldashev, $K$ istorii torgovykh $i$ posolskikh sviazei, 90-1.

59 On Daudov's biography, see Selifontov, "Ocherk sluzhebnoi deiatel'nosti," 141; D.L., “Avtobiografiia stol'nika V. A. Daudova," 5-20.

60 An extract from the tsar's instruction (nakaz) to envoys Vasily Daudov and Muhammed Yusuf Kasymov, 20 February
1675, Antonova et al., Russko-indiiskie otnosheniia, 191-2 (doc. 110).

61 The Bukharan inn in Astrakhan (Bukharskii gostinnyi dvor) was particularly important here, both as a marketplace and as an enclave for Central Asian émigré and mercantile groups. It was known as a marketplace and residence for foreigners and out-of-town merchants; see Burton, The Bukharans, 460,492 . On the biography of Kasymov, see Kobenko, Nakaz Tsarya Alekseia Mikhailovicha, iv.

62 NIAII RAN, f. 113, op. 1, d. 94, 11. 206-8; 213-13 ob.

63 Like earlier Muscovite diplomats who had been dispatched to the Mughal court, Kasymov was entrusted with a missive on behalf of the Russian tsar to Aurangzeb composed in three copies: Russian, Turkic (Tatar), and Latin. It seems that all of them had an equivalent status as all three were written "on the large folio of Alexandrian paper," and stamped "with the same large [regal] seal"; see NIAII RAN, f. 113, op. 1, d. 93,11. 195, 229 ob. Both the facsimile and the edition of the tsar's letters to Aurangzeb in Turkic are available in Antonova et al., Russko-indiiskie otnosheniia, 225-9.

64 Letter (otpiska) of Vasily Daudov from Bukhara, 20 March 1676, Samoilovich, MIUTT, 226-8 (doc. 89).

65 Interview of the tolmach I. Gorny, August 1676, in Iuldashev, $K$ istorii torgovykh i posol'skikh sviazei, 106-8.

66 See Antonova et al., Russko-indiiskie otnosheniia, 227.

67 Though Kasymov's ambassadorial report has not survived, the itinerary of the Russian envoy from Bukhara to Kabul was traced in detail on the basis of other concomitant materials in the latter half of the nineteenth century by the Russian author Minaev; see his Svedeniia o stranakh, 217-28.

68 For this figure see Navvāb Șamșām ud-Daula Shāh Navāz Khān and 'Abd ul-Hayy, The Maāthir-ul-Umarā, 243-6. 
69 Translation of the letter of the Padishah Aurangzeb to the governor of Kabul Mukarram Khan (2 March 1676), see Antonova et al., Russko-indiiskie otnosheniia, 222 (doc. 128).

70 Ulianitsky, Snosheniia Rossii s Srednei Azieiu i Indeiu, 54.

71 Baikova, Rol' Srednei Azii, 52-3; 5771; Levi, The Indian Diaspora, 230-1.

72 RGADA, f. 56, op. 2, god 1696, d. 5. For the facsimile of the firman as well as the Russian translation, see Antonova et al., Russko-indiiskie otnosheniia, 368-70 (doc. 256).

73 Ulianitsky, Snosheniia Rossii s Srednei Azieiu i Indeiu, 56; for a detailed description of Malenky's voyage to India, see Antonova et al., Russko-indiiskie otnosheniia, 371-3 (doc. 258).

74 Monahan, The Merchants of Siberia, 43.

75 NIAII RAN, f. 113, op. 1, d. 94 (Posol'skie knigi snoshenii Rossii $s$ Khivoiu), 11. 60-60 ob., 90; GAAO, f. 394 , op. 1, d. 1570,1 . 8. On some occasions, a separate list of merchants (savdāgar) who came along with the envoy was submitted to the Russian authorities; GAAO, f. 394, op. 1, d. $1570,1.8$.

76 This was the case, for instance, of Abdurrahim Azhizov, the envoy of Ārang Khān (r. 1689-95) to Moscow in 1689-91; see NIAII RAN, f. 113, op. 1, d. 94,11. 142 ob.-144; in 1641 another Khivan emissary, Nazar Malik, behaved in similar fashion; see Samoilovich, MIUTT, 160-4 (doc. 48).

77 Thus, for instance, the Khivan envoy Abdurrahim Azhizov arrived in 1689 along with fifty associates and hangers-on, who all received kormovye den'gi for the next three years, being from time to time granted by the Russian tsar the right to carry out commercial operations in various places of Muscovy, see NIAII RAN f. 113, op. 1, d. 94,11. 183-3 ob.

78 On the conditions of the New Commercial Code with regard to "eastern trade," see Burton, The Bukharans, 486-8.
79 Burton, The Bukharans, 488; Kotilaine, Russia's Foreign Trade, 472.

80 See NIAII RAN, f. 113, op. 1, d. 94,11. 191-91 ob.

81 Ibid., 11. 63-4; 11.112 ob.-113; 191 ob.

82 Ibid., 11. 42-42 ob.; 63-63 ob.

83 Ibid., 11. 42-42 ob.

84 Ibid., 1162 ob.-64 ob.

85 NIAII RAN, f. 113, op. 1, d. 94,1. 35.

86 On Julfa Armenians' silk monopoly, see Matthee, Anti-Ottoman Politics, 752-3.

87 NIAII RAN, f. 113 , op. 1, d. 93,11. 58 ob.-63.

88 Veselovsky, "Posol'stvo Mikhaila Nikiticha Tikhanova," 182-3.

89 Samoilovich, MIUTT, 168-70 (doc. 55).

90 Burton, The Bukharans, 291.

91 See for instance the list of merchandise brought by Khivan envoy Muhammad Amin Bahadur in Astrakhan in 1641. A good deal of imported goods was of Indian origin; see Samoilovich, MIUTT, 168 (doc. 54).

92 Monahan, The Merchants of Siberia, 60.

93 For the similar trajectories of the Russian slave trade, see NIAII RAN, f. 113, op. 1, d. 94,11. 10-10 ob., 1111 ob., 155-55 ob.; on Central Asia as a nodal point of the regional slave trade in the early modern period, see also Levi, "Hindus Beyond the Hindu Kush," 279; Eden, Slavery and Empire.

94 For the petitions of the Russian slaves in Bukhara, Urgench, and Khiva to the Russian tsar in 1670, see Truvorov, "Nakaz Pazukhinym," 23. For similar petitions to the Romanov autocrats on behalf of the Russian subjects kept in slavery in Khiva and Bukhara, see NIAII RAN, f. 113, op. 1, d. 94,11. 10 ob.-11 ob; d. 93,11. 156 ob.-157.

95 Truvorov, "Nakaz Pazukhinym," 23; Ivan Fedotov, a Russian envoy to Khiva in 1669 also reported about a large number of the Russian captives in Khorezm; see Veselovsky, "Posol'stvo v Khivu," 79.

96 NIAII RAN, f. 113, op. 1, d. 94,11. 10 ob.-11 ob.

97 Truvorov, "Nakaz Pazukhinym," 59. 
98 On the details of this embassy, see RGADA, f. 134, op. 1, d. 41,11. 44$51 \mathrm{ob}$.

99 For more on the Karagan Landing located in the Mangyshlaq Peninsula, which from the 1640s onwards became the main staging post in trade and diplomatic communications between the Central Asian khanates and Muscovy, see Chuloshnikov, "Torgovlia Moskovskogo gosudarstva," 76.

100 RGADA, f. 134, op. 1, d. 4,1. 45 ob. The same proposals were articulated in the Anūsha's letter to the head of Posol'skii Prikaz, Artamon Matveev; see ibid., 11. 45 ob.-46.

101 Extract from the ambassadorial report of Vasily Daudov, 3 July 1677, in ibid., 235 (doc. 95).

102 Recent studies by Michael Khodarkovsky and Peter Poullada provide new insights into the role played by nomad groups-Kalmyks and Turkmens respectively in trade relations between Central Asia and Muscovite Russia. Khodarkovsky, Where Two Worlds Met; Poullada, RussianTurkmen Encounters.

103 Extract from the ambassadorial report of Vasily Daudov, 3 July 1677, in Samoilovich, MIUTT, 235 (doc. 95).

104 On the system of maintenance infrastructure and security on caravan routes in Safavid Iran, see Floor, The Economy of Safavid Persia, 31-40; for the Mughal state, see Dale, Indian Merchants, 46-55.

105 As Romaniello puts it, "there can be no argument that Muscovite Russia was uninformed about the outside world." Moreover, Russian authorities "certainly possessed the necessary knowledge to make better decisions in the future." Yet, Romaniello concludes, they failed to use this information in any effective way; see his "In Friendship and Love," 122.

106 As becomes evident from the correspondence and other documents with regard to the preparation of the Bekovich-Cherkassky expedition to Khiva in 1716-17, nearly all the expertise on India that had been gathered over the previous half-century of diplomatic and commercial engagement was disregarded by the Petrine authorities, who took note only of those reports which provided information regarding the titulature of the Mughal emperors or assortment of gifts that had been taken by the previous envoys, and some details of itinerary. Among more practical steps undertaken in this regard, one may note the interview with a certain Andrey Semenov, who accompanied Semen Malenkii during the latter's mission to India in 1695-1701. See Bychkov, Materialy voenno-uchebnogo arkhiva, docs. XII, XIV, XXXVIII. Again, judging from the text of the interview one may note that the Russian authorities were mostly concerned with the same issues of gifts taken to Mughal emperors, Indian imports and exports, and very superficial details of itinerary.

107 Dale, Indian Merchants, 94.

108 See for instance Schimmelpenninck van der Oye, "Paul's Great Game," 145-50.

109 See for instance Bohlen, "Changes in Russian Diplomacy,” 341-58; Bushkovitch, "Peter and the Seventeenth Century," 447-61.

110 RGADA, f. 397, op. 1, d. 314,11. 3442; RGIA, f. 1374, op.2, d. $2399^{\mathrm{a}}, 11.30-7$.

111 For more on this expedition, see Paolo Sartori's contribution to this issue.

112 On 31 March 1802, the proposal was considered by the Private Committee, a consultative body of the Emperor Alexander I, and received positive feedback from its members; see Kudriashov, "Zubov, graf Valerian Aleksandrovich," 521.

113 Zubov, "Obshchee obozrenie torgovli s Azeiiu," 879-94. 